\title{
Genetic Diversity Estimation in Toria [Brassica rapa (L)] Genotypes Collected from Bastar Plateau
}

\author{
Mahendra*, J. L. Salam, Sonali Kar, Ravi R. Saxena, R. R. Bhanwar, \\ T. Chandrakar, Rakesh Singh and Rohit
}

Department of Genetics and Plant Breeding, S.G. College of Agriculture and Research Station, Jagdalpur- 404001, Chhattisgarh, India

*Corresponding author

\section{A B S T R A C T}

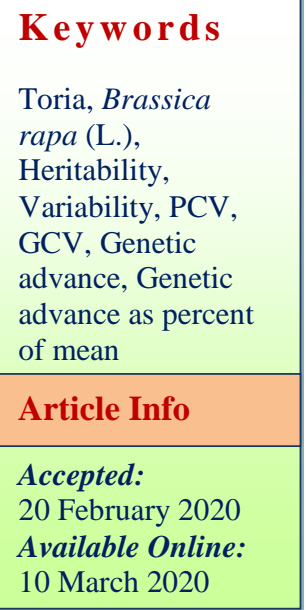

Keywords

Toria, Brassica rapa (L.),

Heritability, GCV, Genetic advance, Genetic advance as percent of mean

Article Info

Accepted:

February 2020

10 March 2020
This experiment was conducted at SGCARS Jagdalpur (C.G.), to assess genetic variability for 11 quantitative characters on 60 toria genotypes including one check Indira toria. The Analysis of variance revealed highly significant differences among the genotypes for all the characters considered under study. High PCV coupled with high GCV was observed for harvest index, seed yield per plant and siliquae per plant indicating a wide range of variation which provides a chance for yield improvement. Highest heritability coupled with highest genetic advance as percent of mean was observed for harvest index indicating additive gene action and the abundant scope for improvement in these traits through simple selection. High PCV, GCV correlated with high heritability and genetic advance as percent of mean were observed for the traits siliquae per plant, harvest index and seed yield per plant.

\section{Introduction}

Brassica rapa (L.) additionally known by name Brassica campestris is a diploid crop having a place within family Brassicaceae. Around 3500 species and 350 genera are available in this family and is one of the monetarily most significant plant family (Rich, 1991). Brassica rapa and Brassica campestris were first characterized as two distinct species by Linnaeus, with Brassica rapa being the turnip type and Brassica campestris the wild weedy type. After some time it was uncovered that the two were similar species so the taxa were consolidated under the name Brassica rapa (Toxopeus et al., 1984).

Rapeseed (Brassica rapa var. toria) belongs to genera Brassica, species rapa having 
chromosome number $(2 \mathrm{n}=20)$. Rapeseed contains three ecotypes viz., toria $[B$. rapa $(\mathrm{L})$ var. toria], yellow sarson $[B . \operatorname{rapa}(\mathrm{L})$ var. yellow sarson] and brown sarson[B. rapa (L) var. brown sarson].

B. rapa originated in the high plateau regions of Iran, Iraq and Turkey (Dixon, 2007) and dispersed naturally to the Central Asia region and Western Mediterranean region. Mustard plant stature extends between 45 and $150 \mathrm{~cm}$. The roots are surface feeder and the root framework has constrained working profundity with a broad parallel spread. The stem is commonly covered with waxy substance. Leaves are borne sessile and are glabrous and shaggy. Flowers have 4 sepals and 4 petals of profound yellow to light yellow shading. Each flower has 6 stamens, 4 with long and 2 with short filaments while the pistil is compound. Fruit are thicker and are crosswise compressed with a beak one-third to half of the total pod length and are comprised of 2 carpels, which are isolated by a bogus septum along these lines giving 2 chambers. Seeds are either yellow or brown with a smooth seed coat. Rape is selfcompatible crop but crosspollination also takes place to some extent. Indian mustard, Gobhisarson and Karan rai group are consists of self-compatible whereas, lotni type brown sarson, toria and taramira group are highly cross pollinated crop varieties. Fertilization of ovules usually results from self-pollination, although interplant outcrossing rates of 20$30 \%$ have been observed (Rakow and Woods, 1987). Bees are the primary pollen vector because the pollen is heavy and sticky and is not carried great distances by wind.

In 2016-17 area, production and productivity of the world, Mustard crop was 733.75 lakh ha, 714.50 lakh tones and $2010 \mathrm{~kg} / \mathrm{ha}$, during 2016. In India area, production and productivity was 57.62 lakh ha, 68.22 lakh tones and $1184 \mathrm{~kg} / \mathrm{ha}$. In Chhattisgarh area, production and productivity 0.43 lakh ha, 0.22 lakh tones and517 kg/ha, respectively. In India this crop is widely cultivated in Rajasthan, Haryana, Madhya Pradesh, Uttar Pradesh, West Bengal, Gujarat, Assam, Jharkhand, Bihar and Chhattisgarh. Rajasthan solely constitutes about 25.49 lakh ha for this crop. In Chhattisgarh area, production and productivity was 0.43 lakh ha, 0.22 lakh tonnes and $517 \mathrm{~kg} / \mathrm{ha}$, respectively (Anon., 2016).

Rapeseed contains around $42 \%$ oil. The seed and oil are utilized as fixings in the readiness of pickles and for enhancing curries and vegetables. The oil is used for human utilization all through Northern India in cooking and searing purposes. It is additionally utilized in the arrangement of hair oils and medicines. It is utilized in cleanser making in blend with mineral oils for grease. The oil cake is utilized as steers feed and compost having 5.2 N, $1.0 \mathrm{P}_{2} \mathrm{O} 5$ and 1.4 $\mathrm{K}_{2} \mathrm{O}$. Due to glucosinolates, mustard cake isn't appropriate for human use as it unfavourably influences protein. Green stems and leaves are a decent wellspring of green grub for dairy cattle. The leaves of youthful plants are utilized as green vegetables as they supply enough sulfur and mineral in the eating regimen. In the tanning business, mustard oil is utilized for relaxing cowhide. Mustard oil contains erucic acid in high sum and it is evacuated before use as palatable oil.

\section{Materials and Methods}

The present study entitled "Characterization and genetic architect analysis of seed yield and its components in Brassica rapa (L.) var. toria." was carried out at the Instructional cum Research Farm of S.G. College of Agriculture and Research Station, Jagdalpur, IGKV Raipur, Chhattisgarh during rabi 201819 , which is located at $\mathrm{N} 19^{\circ} 5^{\prime} 35^{\prime}$ ' longitude E 81'57'37', latitude and at an altitude 
ranging from 530 to 850 meters above mean sea level (MSL) with an annual rainfall 1200 to $1600 \mathrm{~mm}$. The experiment was conducted during rabi2018-19 dating from 05/11/2018 to $23 / 2 / 2019$. During this time period various climatic factors were recorded weekly such as temperature $\left({ }^{\circ} \mathrm{C}\right)$, rainfall $(\mathrm{mm})$, relative humidity, bright hours and number of rainy days. During crop growing period temperature ranges between $34.6^{\circ} \mathrm{C}$ to $6.7^{\circ} \mathrm{C}$. The sum of rainfall pursued during crop growing season was $52.6 \mathrm{~mm}$ whereas average relative humidity was 64.4 and bright hours were 6.8 respectively. The max. rainfall $(39.6 \mathrm{~mm})$ received during $3^{\text {rd }}$ week of December.

\section{Estimation of genetic parameters}

The mean data of all traits was exposed to ANOVA analysis to obtain the estimates of mean sum of squares and mean sum of products and these were utilised for the calculation of following parameters.

\section{Coefficient of variation}

The coefficient of variation (CV) being a unit less measurement, is a good basis for comparing the extent of variation between different characters with different scales.

$\mathrm{CV}=\frac{\mathrm{SD}}{\overline{\mathrm{x}}} \times 100$

The genotypic and phenotypic variance were calculated as per the formulae proposed by Burton (1952).

Genotypic variance ${ }^{\sigma \mathrm{g}^{2}}=$

\section{Number of raplications}

MSS due to genotypes-MSS due to error

Phenotypic variance $\sigma \mathrm{p}^{2}=\sigma \mathrm{g}^{2}+\sigma \mathrm{e}^{2}$ $\sigma \mathrm{g}^{2}=$ Genotypic variance

$\sigma \mathrm{p}^{2}=$ Phenotypic variance

$\sigma \mathrm{e}^{2}=$ Error variance

Phenotypic and genotypic components of variance were estimated by using the formula suggested by Burton and De Vane (1953).

Genotypic coefficient of variability (GCV) $=\frac{\sigma g}{\bar{X}} \times 100$

Phenotypic coefficient of variability $(\mathrm{PCV})=\frac{\sigma \mathrm{P}}{\overline{\mathrm{X}}} \times 100$

Where,

$\sigma g=$ Genotypic standard deviation

$\sigma \mathrm{p}=$ Phenotypic standard deviation

$\bar{X}=$ General mean of character

Sivasubramanian and Menon (1973) categorised PCV and GCV estimates as follows,

20.1 percent and above $=$ High

10.1-20 percent $=$ Moderate

$1-10$ percent $=$ Low

\section{Heritability $\left(h^{2}\right)$}

Broad sense heritability was computed as "the ratio of genetic variance to the total phenotypic variance as suggested by Hanson et al., (1956) and expressed as percentage".

Heritability $\left(h^{2}\right)=\frac{\sigma_{\mathrm{g}}^{2}}{\sigma_{\mathrm{p}}^{2}} \times 100$

Where,

$\sigma^{2} \mathrm{p}=$ Phenotypic variance

$\sigma^{2} \mathrm{~g}=$ Genotypic variance

The heritability percentage was categorized as high, moderate and low as given by Robinson et al., (1949).

60.1 percent and above $=$ High

30.1 -60 percent $=$ Moderate

$0-30$ percent $=$ Low 


\section{Genetic Advance (GA)}

The expected genetic gain for each character was analysed by using the following method suggested by Johnson et al., (1955).

\section{Genetic $\operatorname{advance}(G A)=K \times h^{2} \times \sigma_{p}$}

Where,

$\mathrm{K}=\mathrm{A}$ constant, the value equal to 2.06 at $5 \%$ selection intensity

$\mathrm{h}^{2}=$ broad sense heritability

$\sigma_{\mathrm{p}}=$ phenotypic standard deviation

Genetic advance as percentage of mean (GAM)

$\mathbf{G A M}=\frac{\mathbf{G A}}{\overline{\mathbf{X}}} \times 100$

The range of genetic advance as percent of mean is classified as suggested by Johnson $e t$ al., (1955),

$\mathrm{GA}<10$ per cent $=$ Low

$\mathrm{GA}>10-20$ per cent $=$ Moderate

$\mathrm{GA}>20$ per cent $=$ High

\section{Results and Discussion}

\section{Analysis of variance}

Analysis of variance was performed for eleven quantitative characters including yield and yield attributing traits on sixty genotypes of toria. From the analysis of variance it was observed that mean sum of squares due to genotypes were significant at $5 \%$ level of significance, thus exhibiting the presence of considerable genetic variability for all the characters considered for study. Results pertaining to analysis of variance have been presented in Table 1.This finding in confirmation with the finding of Singh et al., (2013), Tripathi et al., (2013) and Shekhawat et al., (2014).

\section{Genetic variability}

The results pertaining to genetic parameters viz., range, mean, genotypic variance, phenotypic variance, phenotypic coefficient of variation, genotypic coefficient of variation, heritability, genetic advance and genetic advance as per cent of mean were calculated to estimate the amount of genetic variability for different characters. The results related to genetic parameters are presented in the Table 2.

The data of mean and range reveals the extent of phenotypic and genotypic variability of characters under study. Results obtained from these components of genetic parameter indicate presence of abundant amount of genetic variability in the material under present investigation. These findings are similar with the findings of Bind et al., (2014), Singh et al., (2016), Akbar et al., (2008), Aytac and Kinaci (2009) and Lodhi et al., (2014).

Data obtained from the experiment displayed the high PCV and GCV for number of siliquae per plant $(38.49 \%, 38.36 \%)$, seed yield per plant $(40.30 \%, 39.71 \%)$ and harvest index $(68.69,68.52)$.

Moderate PCV and GCV were recorded for days to $50 \%$ flowering $(10.35 \%, 10.05 \%)$, seed per siliqua $(14.71 \%, 14.54 \%)$ and plant height $(17.69 \%, 17.59 \%)$ whereas rest of the traits indicated low PCV and GCV. This estimates of the present study were similar with the findings of Rai et al., (2005), Akbar et al., (2008), Aytac and Kinaci (2009), Bind et al., (2014), Singh et al., (2013), Tripathi et al., (2013), Lodhi et al., (2014), Shekhawat $e t$ al., (2014), Samahegn and Tesfaye (2016) and Hussain et al., (2016). 
Table.1 Analysis of variance for yield and yield attributing characters in toria lines

\begin{tabular}{|c|c|c|c|c|c|c|c|c|c|c|c|c|}
\hline $\begin{array}{c}\text { Source of } \\
\text { variation }\end{array}$ & DF & DFF & DM & PH (cm) & SPP & SPS & SL (cm) & PBPP & SBPP & HI & SYPP & TW (g) \\
\hline Replication & 2 & 0.26 & 2.21 & 10.78 & 8.40 & 1.14 & 0.10 & 0.45 & 0.08 & 147.54 & 109.07 & 0.01 \\
\hline Treatment & 59 & 43.33 & 35.62 & 595.89 & 2162.45 & 15.58 & 0.94 & 0.05 & 0.08 & 646.72 & 84.60 & 0.24 \\
\hline Error & 118 & 0.87 & 0.35 & 2.24 & 4.96 & 0.12 & 0.04 & 0.04 & 0.05 & 1.05 & 0.83 & 0.01 \\
\hline S. Em. & & 0.53 & 0.34 & 0.86 & 3.67 & 0.20 & 0.53 & 0.12 & 0.13 & 0.59 & 0.52 & 0.06 \\
\hline CV (\%) & & 2.49 & 1.57 & 1.87 & 9.03 & 2.23 & 2.49 & 9.53 & 6.94 & 4.79 & 6.86 \\
\hline CD (5\%) & & 1.51 & 0.96 & 2.42 & 10.29 & 0.56 & 1.51 & 1.37 & 0.37 & 1.66 & 1.47 \\
\hline
\end{tabular}

$\mathrm{DF}=$ Degree of freedom, DFF= Days to 50\% flowering, DM= Days to maturity, $\mathrm{PH}=$ Plant height, $\mathrm{SPP}=$ Siliquae per plant, $\mathrm{SPS}=\mathrm{Seed}$ per siliqua, $\mathrm{SL}=\mathrm{Siliquae}$ length, $\mathrm{PBPP}=$ Primary branches per plant, $\mathrm{SBPP}=$ Secondary branches per plant, $\mathrm{HI}=$ Harvest index, SYPP= Seed yield per plant, $\mathrm{TW}=\mathrm{Test}$ weight. 
Table. 2 Genetic parameters of variation for seed yield and its component traits in toria

\begin{tabular}{|c|c|c|c|c|c|c|c|c|}
\hline \multirow[t]{2}{*}{ S.No. } & \multirow[t]{2}{*}{ Characters } & \multirow[t]{2}{*}{ Mean } & \multicolumn{2}{|c|}{ Range } & \multicolumn{2}{|c|}{ Coefficient of variation(\%) } & \multirow[t]{2}{*}{$h^{2} b s(\%)$} & \multirow[t]{2}{*}{ GAM (\%) } \\
\hline & & & Min & Max & PCV & GCV & & \\
\hline 1 & DFF & 37.43 & 32.33 & 49.00 & 10.35 & 10.05 & 94.20 & 20.09 \\
\hline 2 & $\mathrm{DM}$ & 103.58 & 95.66 & 108.66 & 3.35 & 3.31 & 97.09 & 6.71 \\
\hline 3 & PH & 79.95 & 50.4 & 114.13 & 17.69 & 17.59 & 98.87 & 36.03 \\
\hline 4 & SPP & 69.90 & 49.26 & 215.86 & 38.49 & 38.36 & 99.31 & 78.75 \\
\hline 5 & SPS & 10.60 & 11.93 & 26.00 & 14.71 & 14.54 & 97.70 & 29.62 \\
\hline 6 & SL & 6.00 & 4.66 & 7.23 & 9.84 & 9.13 & 86.01 & 17.44 \\
\hline 7 & PBPP & 2.24 & 2.00 & 2.53 & 9.70 & 2.12 & 4.77 & 0.95 \\
\hline 8 & SBPP & 3.31 & 2.93 & 3.93 & 7.60 & 3.09 & 16.57 & 2.59 \\
\hline 9 & HI & 21.41 & 3.16 & 83.36 & 68.69 & 68.52 & 99.51 & 98.81 \\
\hline 10 & SYPP & 13.30 & 9.02 & 41.90 & 40.30 & 39.71 & 97.1 & 80.61 \\
\hline 11 & TW & 2.99 & 2.46 & 3.60 & 9.98 & 9.30 & 86.77 & 17.85 \\
\hline
\end{tabular}

$\mathrm{DFF}=$ Days to $50 \%$ flowering, $\mathrm{DM}=$ Days to maturity, $\mathrm{PH}=$ Plant height, $\mathrm{SPP}=$ Siliquae per plant, $\mathrm{SPS}=\mathrm{Seed}$ per siliqua, $\mathrm{SL}=$ siliquae length, $\mathrm{PBPP}=$ primary branches per plant, $\mathrm{SBPP}=$ secondary branches per plant, $\mathrm{HI}=$ harvest index, $\mathrm{SYPP}=$ Seed yield per plant, $\mathrm{TW}=\mathrm{Test}$ weight. 
In the present investigation the high heritability was recorded for the characters harvest index $(99.51 \%)$ followed by siliquae per plant $(99.31 \%)$, plant height $(98.87 \%)$, seed per siliqua $(97.70 \%)$, seed yield per plant (97.1\%), days to maturity $(97.09 \%)$, days to $50 \%$ flowering $(94.20 \%)$, test weight $(86.77 \%)$ and siliquae length $(86.01 \%)$ while low heritability was recorded for the characters secondary branches per plant $(16.57 \%)$ and primary branches per plant $(4.77 \%)$.

Genetic advance as per cent of means was high in case of harvest index $(98.81 \%)$, seed yield per plant $(80.61 \%)$, siliquae per plant (78.75\%), plant height $(36.03 \%)$, seed per siliqua $(29.62 \%)$ and days to $50 \%$ flowering $(20.09 \%)$ whereas moderate in case of test weight $(17.85 \%)$ and siliquae length $(17.44 \%)$. However, it was low in case of days to maturity $(6.71 \%)$, secondary branches per plant $(2.59 \%)$ and primary branches per plant $(0.95 \%)$ respectively.

High heritability estimates in broad sense correlated with high genetic advance as per cent of mean was observed for days to $50 \%$ flowering, plant height, siliquae per plant, seed per siliqua, harvest index and seed yield per plant indicating predominant role of additive gene action for expression of these traits. As additive gene action is pronounced in the expression of these characters, early generation selection would be effective in breeding program.

High PCV, GCV correlated with high heritability and genetic advance as percent of mean were observed for the traits siliquae per plant, harvest index and seed yield per plant. Thus indicating that these were the traits which must be considered while selecting plant for the crop improvement. The findings of present study were in agreement with the findings of Rai et al., (2005), Bind et al.,
(2013), Shekhawat et al., (2014) and Hussain et al., (2016).

\section{References}

Akbar, M., Tahira, Babar, M.A. and Hussain, M. 2008.Combining Ability Studies in Rapeseed (Brassica napus). Int. J. Agric. Biol., 10(2): 205-208.

Anonymous, 2016-17. Government of India.Status paper on oilseeds.

Aytac, Z. and Kinac1 G. 2009.Genetic variability and association studies of some quantitative characters in winter rapeseed (Brassica napus L.) African J. Biotech., 8 (15): 3547-3554.

Bind, D., Singh, D. and Dwivedi, V.K. 2014. Genetic variability and character association in Indian mustard [Brassica juncea (L.) czerns\&coss] Agric. Sci. Digest, 34 (3): 183-188.

Burton, G. W. and Devane, E.W. 1953. Estimating heritability in tall Fescue (Fescue arundinacea) from replicated clonal material. Agro.J., 45: 478- 481.

Dixon, G.R. 2007.Vegetable Brassicas and related crucifers. Cambridge, Mass. CABI, :1-339.

Hanson, C.H., Robinson, H.F., Comstock, R.E. 1956. Biometrical studies of yield in segregating population of Korean Lespedeza. Agro. J., (48): 268-272.

Hussain, Md. A., Hussain, Md. S., Bhuiyan Md. S.R., Zeba, N. and Mohsin, Md, S. 2016. Field performance and genetic analysis in some advanced lines of Mustard (Brassica rapa L.). A Sci. J. Krishi Foundation The Agriculturists, 14(1): 112-121.

Johnson, H.W., Robinnson, H.F. and Comstock, R.E. 1955. Genotypic and phenotypic correlation in soybean and their implication in selection. Agron. J., (47): 314-318.

Johnson, H.W., Robinnson, H.F. and Comstock, R.E. 1955. Genotypic and 
phenotypic correlation in soybean and their implication in selection. Agro. J., 47: 447-483.

Lodhi, B., Thakral, N.K., Ram, A. and Amit, S. 2014. Genetic variability, association and path analysis in Indian mustard (Brassica juncea L.). J. Oilseed Brassica, 5(1): 50-55.

Rai, S.K., Verma, A. and Pandey, D.D. 2005. Analysis of combining ability in Indian mustard (Brassica juncea L. Czern and Coss). Plant Archives, 5(1): 69-75.

Rakow, G. and Woods, D.L. 1987. Outcrossing in rape and mustard under Saskatchewan prairies conditions. Can. J. Plant Sci., 67: 147-151.

Rich, T.C.G. 1991. Crucifers of Great Britain and Ireland. Botanical Society of the British Isles, London, 336.

Robinson, H. F., Compstock, R. E. and Harey, P. H. 1949.Estimates of heritability and degrees of dominance in corn.Agron. J., 43: 353-359.

Shekhawat, G.,Jadeja C., Singh, J. and Shekhawat, R.S. 2014. Character association studies among yield and its component characters in Indian mustard (Brassica juncea L. Czern\&Coss). The Biosean, 9(2): 685-688.

Singh, A., Avtar, R., Singh, D., Sangwan, O. and Balyan P. 2013. Genetic variability, character association and path analysis for seed yield and component traits under two environments in Indian mustard. J. Oilseed Brassica, 4(1): 4348.

Sivasubramanian, S.S. and Menon, M.P. 1973.Genotypic and phenotypic variability in rice, Madras Agric. J., 60: 1093-1096.

Toxopeus, H., Oost, E.H. and Reuling, G. 1984. Current aspects of the taxonomy of cultivated Brassica species. The use of $B$. rapa $L$. versus $B$. campestris $L$. and a proposal for a new intraspecific classification of $B$. rapa L. Crucifer Newsletter, 9:55-57.

Tripathi, N., Kumar, K. andVerma, O.P. 2013. Genetic variability, heritability and genetic advance in Indian Mustard (Brassica juncea L. Czern and Coss.) for Seed Yield and it's contributing attributes under normal and saline/Alkaline conditions. Int. J. Sci. Res., 6:14.

Semahegn, Y.,Tesfaye, M. 2016. Varibility, heritability and genetic advance analysis for some morphological characters in oilseed Brassica breeding lines. Molecular plant Breeding. 7 (20):1-8.

\section{How to cite this article:}

Mahendra, J. L. Salam, Sonali Kar, Ravi R. Saxena, R. R. Bhanwar, T. Chandrakar, Rakesh Singh and Rohit. 2020. Genetic Diversity Estimation in Toria [Brassica rapa (L)] Genotypes Collected from Bastar Plateau. Int.J.Curr.Microbiol.App.Sci. 9(03): 2577-2584. doi: https://doi.org/10.20546/ijcmas.2020.903.295 